\title{
Pemberian Skor Dan Sistem Penilaian Dalam Pembelajaran
}

Abil Thoriq Syahputra ${ }^{1}$, Nurjannah Nurjannah ${ }^{2}$, Muhammad Arsyam ${ }^{3}$

${ }^{1}$ Sekolah Tinggi Agama Islam (STAI) Darul Dakwah Wal-Irsyad (DDI) Kota Makassar, Indonesia Email: abilthoriq17061996@gmail.com

${ }^{2}$ Sekolah Tinggi Agama Islam (STAI) Darul Dakwah Wal-Irsyad (DDI) Kota Makassar, Indonesia

Email: sittinurjannah170696@gmail.com

${ }^{2}$ Sekolah Tinggi Agama Islam (STAI) Darul Dakwah Wal-Irsyad (DDI) Kota Makassar, Indonesia

Email: arsyam0505@gmail.com

\begin{abstract}
Abstrak :
Pemberian skor dan sistem penilaian merupakan proses yang penting dalam pendidikan, terutama di indonesia, karna dari hasil pemberian skor dan sistem penilaian itu akan terukur kompetensi, perilaku belajar, danhasil belajar peserta didik dalam periode waktu tertentu sebagai dasar pertimbangan dan mengetahui kinerja peserta didik. Artikel ini menjelaskan dengan gamblang dan terperinci mengenai pemberian skor dan sistem penilaian dalam pendidikan.
\end{abstract}

Kata Kunci : Pemberian Skor, Sistem Penilaian

\section{A. PENDAHULUAN}

Evaluasi adalah suatu proses merencanakan, memperoleh dan menyediakan informasi yang sangat diperlukan untuk membuat alternatif-alternatif keputusan. Sesuai dengan pengertian tersebut maka setiap kegiatan evaluasi atau penilaian merupakan suatu proses yang sengaja direncanakan untuk memperoleh informasi atau data. Berdasarkan data tersebut kemudian dicoba membuat suatu keputusan. Sudah barang tentu informasi atau data yang dikumpulkan itu haruslah data yang sesuai dan mendukung tujuan evaluasi yang direncanakan.

Dalam hubungan dengan kegiatan pengajaran, evaluasi adalah suatu proses yang sistematis untuk menentukan atau membuat keputusan sampai sejauh mana tujuan-tujuan pengajaran telah dicapai siwa.

Dengan kata-kata yang berbeda evaluasi pendidikan ialah penaksiran terhadap pertumbuhan dan kemajuan siswa ke arah tujuan-tujuan atau nilai-nilai yang telah ditetapkan di dalam kurikulum. Dalam dunia pendidikan pasti dilakukan suatu evaluasi, salah satunya dengan cara tes dikumpulkan dan kemudian dilakukan penilaian dan pemberian skor. Dan dalam makalah ini akan membahas sedikit tentang pemeberian skor dan penilaian. 


\section{B. PEMBAHASAN}

\section{Kriteria Ketuntasan Minimal (KKM)}

Kriteria ketuntasan minimal (KKM) adalah tingkat pencapaian kompetensi dasar mata pelajaran oleh peserta didik per mata pelajaran. KKM ditetapkan oleh sekolah pada awal tahun pelajaran dengan memperhatikan:

1. Tingkat Kompleksitas: kesulitan dan kerumitan setiap Kompetensi Dasar (KD) dan indikator yang harus dicapai oleh peserta didik.

2. Daya dukung: ketersedian tenaga, sarana dan prasarana pendidikan, biaya operasional pendidikan, kepedulian stakeholder sekolah, manajemen sekolah.

3. Intake: (kemampuan rata-rata peserta didik) untuk kelas VII SMP atau kelas X SMA bisa berdasarkan hasil seleksi Penerimaan Peserta didik Baru (PPDB), atau Nilai Ujian Nasional (NUN), nilai raport kelas 6 SD atau IX SMP. Untuk kelas VIII, IX SMP atau kelas XI, XII SMA bisa berdasarkan KKM pada semester atau kelas sebelumnya.

Berdasarkan Permendikbud 81 A tahun 2013 tentang Implementasi Kurikulum dan Pedoman Umum Pembelajaran dinyatakan bahwa. Ketuntasan minimal untuk seluruh kompetensi dasar pada kompetensi pengetahuan dan kompetensi keterampilan yaitu 2.66 (B-)

Untuk KD-KD yang terdapat pada KI-3 dan KI-4, peserta didik dinyatakan tuntas belajar apabila pencapaian nilai $\geq 2.66$ dari hasil test formatif. Untuk KD pada KI-1 dan KI-2, ketuntasan peserta didik dilihat dari sikap seluruh mata pelajaran, jika jika profil sikap peserta didik secara umum berada pada kategori baik (B) menurut standar yang ditetapkan satuan pendidikan yang bersangkutan maka ia dinyatakan tuntas.

Implikasi dari ketuntasan belajar tersebut adalah sebagai berikut:

a) Untuk KD pada KI-3 dan KI-4, diberikan remedial individual sesuai dengan kebutuhan peserta didik yang memperoleh nilai kurang dari 2.66 .

b) Untuk KD pada KI-3 dan KI-4, diberikan kesempatan untuk melanjutkan pelajarannya ke KD selanjutnya kepada peserta didik yang memperoleh nilai 2.66 atau lebih dari 2.66

c) Untuk KD pada KI-3 dan KI-4, diadakan remedial klasikal sesuai dengan kebutuhan apabila lebih dari $75 \%$ peserta didik memperoleh nilai kurang dari 2.66 
d) Untuk KD pada KI-1 dan KI-2. Peserta didik yang secara umum profil sikapnya belum berkategori baik, maka dilakukan pembinaan secara holistik (oleh guru kelas, matapelajaran, guru BK, dan orang tua).

Hal yang harus diperhatikan dalam menentukan KKM adalah hitung jumlah Kompetensi Dasar (KD) setiap mata pelajaran setiap kelas dan penentukan kekuatan/nilai untuk setiap aspek/komponen, sesuaikan dengan kemampuan masing-masing aspek:

a) Aspek Kompleksitas: semakin komplek (sukar) KD maka nilainya semakin rendah tetapi semakin mudah KD maka nilainya semakin tinggi. Tingkat kesulitan materi dipandang dari sudut penguasaan guru terhadap materi tersebut. Semakin baik penguasaan guru terhadap materi semakin kecil tingkat kompleksitasnya.

b) Aspek Sumber Daya Pendukung: semakin tinggi sumber daya pendukung maka nilainya semakin tinggi.

c) Aspek Intake: semakin tinggi kemampuan awal siswa (intake) maka nilainya semakin tinggi.

Jumlahkan nilai setiap komponen, selanjutnya dibagi 3 untuk menentukan KKM setiap KD dan Jumlahkan seluruh KKM KD, selanjutnya dibagi dengan jumlah KD untuk menentukan KKM mata pelajaran serta KKM setiap mata pelajaran pada setiap kelas tidak sama tergantung pada kompleksitas KD, daya dukung, dan potensi (Inteks) siswa.

Panduan Konversi skor dari (1-100) ke (1-4)

\begin{tabular}{|c|c|c|c|}
\hline INTERVAL SKOR & HASIL KONVERSI & HASIL KONVERSI & KRITERIA SIKAP \\
\hline $96-100$ & 4.00 & $\mathrm{~A}$ & $\mathrm{SB}$ \\
\hline $91-95$ & 3.66 & $\mathrm{~A}-$ & $\mathrm{B}$ \\
\hline $86-90$ & 3.33 & $\mathrm{~B}+$ & \\
\hline $81-85$ & 3.00 & $\mathrm{~B}$ & $\mathrm{C}$ \\
\hline $75-80$ & 2.66 & $\mathrm{~B}-$ & \\
\hline $70-74$ & 2.33 & $\mathrm{C}+$ & \\
\hline $65-69$ & 2.00 & $\mathrm{C}$ & $\mathrm{K}$ \\
\hline $60-64$ & 1.66 & $\mathrm{C}-$ & \\
\hline $55-59$ & 1.33 & $\mathrm{D}+$ & $\mathrm{D}$ \\
\hline$<54$ & 1.00 & & \\
\hline
\end{tabular}

Keterangan: SB: Sangat Baik, B: Baik, C: Cukup, K: Kurang 
Cara penentuan KKM: Dengan cara memberikan poin:

\begin{tabular}{|c|c|c|c|c|}
\hline \multirow{2}{*}{ NO. } & \multirow{2}{*}{ KRITERIA NILAI } & \multicolumn{3}{|c|}{ NILAI } \\
\cline { 3 - 5 } & & TINGGI & SEDANG & RENDAH \\
\hline 1 & KOMPLEKSITAS & 1 & 2 & 3 \\
\hline 2 & DAYA DUKUNG & 3 & 2 & 1 \\
\hline 3 & INTAKE & 3 & 2 & 1 \\
\hline
\end{tabular}

Jika indikator memiliki kriteria: kompleksitas rendah, daya dukung tinggi dan intake siswa sedang maka nilai KKM-nya adalah: $(3+3+2): 9$ x $100=88,89$. Dengan memberikan rentang nilai

\begin{tabular}{|c|c|c|c|c|}
\hline \multirow{2}{*}{ NO. } & \multirow{2}{*}{$\begin{array}{c}\text { KRITERIA } \\
\text { NILAI }\end{array}$} & TINGGI & SEDANG & RENDAH \\
\cline { 3 - 5 } & KOMPLEKSITAS & $50-54$ & $65-80$ & $81-100$ \\
\hline 1 & DAYA DUKUNG & $81-100$ & $65-80$ & $50-64$ \\
\hline 2 & INTAKE & $81-100$ & $65-80$ & $50-64$ \\
\hline 3 & &
\end{tabular}

Nilai KKM indikator adalah rata-rata dari nilai ketiga kriteria yang ditentukan. Contoh: kompleksitas sedang (75), daya dukung tinggi (95), dan intake sedang (70), maka nilai KKM indikator: $(75+95+70): 3=80$.

\section{Teknik Pemberian Skor}

Penskoran merupakan langkah pertama dalam proses pengolahan hasil tes. Penskoran adalah suatu proses pengubahan jawaban-jawaban tes menjadi angka-angka. Angka-angka hasil penskoran itu kemudian diubah menjadi nilai-nilai melalui suatu proses pengolahan tertentu. Penggunaan simbol untuk menyatakan nilai-nilai itu ada yang dengan angka, seperti angka dengan rentangan $0-10,0-100,0-4$, dan ada pula yang dengan huruf $A, B, C, D$, dan $E$ (Ngalim Purwanto, 1994:70). Cara menskor hasil tes biasanya disesuaikan dengan bentuk soalsoal tes yang dipergunakan, apakah tes objektif atau tes essay, atau dengan bentuk lain.

1) Pemberian skor untuk tes bentuk benar-salah

Dalam menentukan angka atau skor untuk tes bentuk benar-salah ini kita dapat menggunakan 2 cara, yaitu: (1) Tanpa denda, dan (2) Dengan denda. 
Tanpa denda adalah banyaknya angka yang diperoleh siswa sebanyak jawaban yang cocok dengan kunci. Sedangkan dnegan denda (karena diragukan ada unsur tebakan), digunakan

2) Macam rumus berikut (Zainal Arifin, 2009:225-226).

Pertama, dengan rumus:

$\mathrm{S}=\mathrm{R}-\mathrm{W}$

$\mathrm{S}=$ Score

$\mathrm{R} \quad$ = Right

$\mathrm{W}=\mathrm{Wrong}$

Skor yang diperoleh siswa sebanyak jumlah soal yang benar dikurangi dengan jumlah soal yang salah.

Kedua, dengan rumus:

$\mathrm{S}=\mathrm{T}-2 \mathrm{~W}^{\mathrm{T}}$

$\mathrm{T}=$ Total, artinya jumlah soal dalam tes

3) Pemberian skor untuk tes bentuk jawab singkat (short answer test)

Tes bentuk jawab singkat adalah bentuk tes yang menghendaki jawaban berbentuk kata atau kalimat pendek. Maka jawaban untuk tes tersebut tidak boleh berbentuk kalimat-kalimat panjang, tetapi harus sesingkat mungkin dan mengandung satu pengertian. Dengan persyaratan inilah maka bentuk tes ini dpaat digolongkan ke dalam bentuk tes objektif.

Dengan mengingat jawaban yang hanya satu pengertian saja. Maka angka bagi tiap nomor soal mudah ditebak. usaha yang dikeluarkan oleh siswa sedikit, tetapi lebih sulit daripada tes bentuk betul-salah atau pilihan ganda. Dalam tes bentuk ini, sebaiknya tiap soal diberi angka 2 (dua). Tetapi apabila jawabannya bervariasi misalnya lengkap sekali, lengkap, dan kurang lengkap, maka angkanya dapat dibuat bervariasi pula misalnya 2, 1,5, dan 1

4) Pemberian skor untuk tes bentuk menjodohkan (matching)

Pada dasarnya tes bentuk menjodohkan adalah tes bentuk pilihan ganda, dimana jawabanjawaban dijadikan satu, demikian pula pertanyaan-pertanyaannya. Karena tes bentuk menjodohkan adalah tes bentuk pilihan ganda yang lebih kompleks. Maka angka yang diberikan sebagai imbalan juga harus lebih banyak. Sebagai ancar-ancar dapat ditentukan bahwa angka untuk tiap nomor adalah 2 (dua). 
5) Pemberian skor untuk tes bentuk uraian

Sebelum menyusun sebuah tes uraian sebaiknya kita tentukan terlebih dahulu pokokpokok jawaban yang kita kehendaki. Dengan demikian, maka akan mempermudah kita dalam mengoreksi tes itu. Tidak ada jawaban yang pasti terhadap tes bentuk uraian ini. Jawaban yang kita peroleh akan sangat beraneka ragam, beda antara siswa yang satu dengan siswa yang lain.

Langkah-langkah pemberian skornya adalah:

a) Membaca soal pertama dari seluruh siswa untuk memperoleh gambaran mengenai lengkap tidaknya jawaban yang diberikan siswa secara keseluruhan.

b) Menentukan angka untuk soal pertama tersebut. Misalnya jika jawabannya lengkap diberi angka 5, kurang sedikit diberi angka 4, begitu seterusnya.

c) Mengulangi langkah-langkah tersebut untuk soal tes kedua, ketiga, dan seterusnya.

d) Menjumlahkan angka-angka yang diperoleh oleh masing-masing siswa untuk tes bentuk uraian.

Alternatif kedua untuk pemberian skor pada tes bentuk uraian adalah dengan menggunakan cara pemberian angka yang relatif. Misalnya untuk sesuatu nomor soal jawaban yang paling lengkap hanya mengandung 3 unsur, padahal yang kita kita menghendaki 5 unsur, maka kepada jawaban yang paling lengkap itulah kita berikan angka 5, sedangkan yang menjawab hanya 2 atau 1 unsur, kita beri angka lebih sedikit, yaitu misalnya 3,5; 2; 1,5; dan seterusnya.

Apa yang telah diterangkan di atas ini adalah cara memberikan angka dengan menggunakan atau mendasarkan pada norma kelompok(norm referenced test). Apabila dalam memberikan angka menggunakan atau mendasarkan pada standar mutlak (Criterion referenced test), maka langkah-langkahnya adalah:

a) Membaca setiap jawaban yang diberikan oleh siswa dan dibandingkan dengan kunci jawaban yang telah disusun.

b) Membubuhkan skor di sebelah kiri setiap jawaban. Ini dilakukan per nomor soal.

c) Menjumlahkan skor-skor yang telah dituliskan pada setiap soal.

Dengan cara ini maka skor yang diperoleh siswa tidak dibandingkan dnegan jawaban paling lengkap yang diberikan oleh siswa lain, tetapi dibandingkan dengan jawaban lengkap yang dikehendaki dan sudah ditentukan oleh guru 
6) Pemberian skor untuk tes bentuk tugas Tolak ukur yang digunakan sebagai ukuran keberhasilan tugas adalah:
a) Ketepatan waktu
b) Bentuk fisik pengerjaan tugas yang menandkan keseriusan dalam mengerjakan tugas.
c) Sistematika yang menunjukkan alur keruntutan pikiran.
d) Kelengkapan isi menyangkut ketuntasan penyelesaian dan kepadatan isi.

e) Mutu hasil tugas, yaitu kesesuaian hasil dengan garis-garis yang sudah ditentukan oleh guru.

Dalam mempertimbangkan nilai akhir perlu dipikirkan peranan masing-masing aspek kriteria tersebut, misalnya:
a. Ketepatan waktu, diberi bobot 2
b. Bentu fisik, diberi bobot 1
c. Sistematika, diberi bobot 3
d. Kelengkapan isi, diberi bobot 3
e. Mutu hasil, diberi bobot 3

Maka nilai akhir untuk tugas tersebut diberikan rumus:

NAT $=$ NAT adalah Nilai Akhir Tugas

7) Cara Memberi Skor untuk Domain Psikomotor

Dalam domain psikomotor, pada umumnya yang diukur adalah penampilan atau kinerja. Untuk mengukurnya, guru dapat menggunakan tes tindakan melalui simulasi, unjuk kerja atau tes identifikasi. Salah satu instrument yang dapat digunakan adalah skala penilaian yang terentang dari Sangat Baik(5), Baik(4), Cukup(3), Kurang Baik(2), sampai dengan Tidak Baik(1) 8) Cara Memberi Skor Skala Sikap (Afektif)

Untuk mengukur sikap dan minat belajar siswa, guru dapat menggunakan alat penilaian model skala, seperti sikap dan skala minat. Skala sikap dapat menggunakan lima skala, yaitu; Sangat Setuju (SS), Setuju (S), Tidak Tahu (TT), Tidak Setuju (TS), dan Sangat Tidak Setuju (STS). Skala yang digunakan 5,4,3,2,1 (untuk pernyataan positif) dan 1,2,3,4,5 (untuk pernyataan negative). Begitupun dengan skala minat, guru dapat menggunakan lima skala, seperti Sangat Berminat (SB), Berminat (B), Sama Saja (SS), Kurang Berminat (KB), dan Tidak Berminat (TB). 


\section{Penilaian Acuan Patokan dan Penilaian Acuan Normatif}

Sesudah evaluasi sumatif dibuat, guru biasnya menetapkan nilai, skor, atau grade hasil kerja siswa. Guru sering merasa puas dalam menetapkan skor para siswa yang diajarnya, tetapi juga tidak jarang, ia menggerutu atau kecewa, karena hasil belajar para siswanya ternyata banyak yang jeblok atau di bawah rerata skor yang telah ditetapkan. Dalam memutuskan skor atau grade hasil belajar, para guru biasanya akan memilih satu diantara dua dasar penilaian, yaitu:

1) Penilaian Acuan Patokan

Penilaian Acuan Patokan (PAP) juga sering disebut criterion evaluation merupakan pengukuran lain dengan menggunakan acuan beda. Dalam pengukuran ini penampilan siswa dikomparasikan dengan kriteria yang telah ditentukan terlebih dahulu dalam tujuan instruksional, bukan dengan penampilan siswa lain. Keberhasilan siswa dalam prosedur acuan patokan tergantung pada penguasaan materi atas kriteria yang telah dijabarkan dalam item-item pertanyaan guna mendukung tujuan instruksional (M.Sukardi, 2015:59).

2) Penilaian Acuan Normatif

Penilaian Acuan Normatif (PAN) merupakan pendekatan klasik, karena tampilan pencapaian hasil belajar siswa pada suatu tes dibandingkan dengan penampilan siswa lain yang mengikuti tes yang sama. Pengukuran ini digunakan sebagai metode pengukuran yang menggunakan prinsip belajar kompetitif. Menurut prinsip pengukuran normatif, tes baku pencapaian diadministrasi dan penampilan baku normatif dikalkulasi untuk kelompok-kelompok pengambil tes yang bervariasi. Skor yang dihasilkan siswa dalam tes yang sama dibandingkan dengan hasil populasi atau hasil keseluruhan yang telah dibakukan.

Guru kelas kemudian mengikuti asas yang sama, mengukur pencapaian hasil belajar seorang siswa, dengan tetap membandingkan terhadap siswa lain dalam tes yang sama. Seperti dalam evaluasi empiris, guru melakukan pengukuran, mengadministrasi tes, menghitung skor, merangking skor, dari tes tertinggi sampai yang terendah, menentukan skor rerata menentukan simpangan baku dan variannya.

Dalam menentukan asas normatif ini, guru kemudian membuat semua grade untuk semua siswa dengan mengaitkannya dengan nilai atau grade $\mathrm{C}$ dan simpangan baku kelas. Pada tes yang tidak dibakukan, siswa pada posisi rerata yang digunakan sebagai acuan dengan penempatan grade yang diperoleh masing-masing siswa. 
3) Perbedaan PAN dan PAP didasarkan atas 3 kriteria:

a. Perbedaan PAP dan PAN ditinjau dari Pengembangan Tes

\begin{tabular}{|c|l|l|}
\hline NO. & \multicolumn{1}{|c|}{ CRT (PAP) } & \multicolumn{1}{|c|}{ NRT (PAN) } \\
\hline 1 & $\begin{array}{l}\text { CRT hanya terdiri dari soal-soal tes } \\
\text { yang didasarkan pada tujuan khusus } \\
\text { pembelajaran }\end{array}$ & $\begin{array}{l}\text { Soal tes tidak hanya berdasarkan pelajaran yang } \\
\text { diterima siswa }\end{array}$ \\
\hline 2 & $\begin{array}{l}\text { Setiap tes mempunyai prasarat agar } \\
\text { siswa menunjukkan "performance" } \\
\text { seperti yang tercantum dalam TIK }\end{array}$ & $\begin{array}{l}\text { Tidak perlu terlebih dahulu menentukan secara } \\
\text { pasti performance yang diharapkan sebelum tes } \\
\text { disusun }\end{array}$ \\
\hline 3 & $\begin{array}{l}\text { Dasar pertimbangan untuk diterimanya } \\
\text { performance tertentu harus berdasarkan } \\
\text { pada kriteria tertentu }\end{array}$ & $\begin{array}{l}\text { Dasar pertimbangan diterimanya performance } \\
\text { berdasarkan hasil perolehan nilai yang didapat } \\
\text { oleh siswa }\end{array}$ \\
\hline 4 & $\begin{array}{l}\text { Mementingkan butir tes sesuai dengan } \\
\text { perilaku (tujuan pembelajaran) }\end{array}$ & \begin{tabular}{l} 
Membuat tes dalam kategori sedang \\
\hline
\end{tabular}
\end{tabular}

b. Perbedaan PAP dan PAN ditinjau dari Standar Performance

\begin{tabular}{|c|c|c|}
\hline NO. & CRT (PAP) & NRT (PAN) \\
\hline 1 & $\begin{array}{l}\text { Standar performance ditentukan dalam } \\
\text { bentuk tingkah laku }\end{array}$ & $\begin{array}{l}\text { Standar performance berdasarkan pada jumlah } \\
\text { pertanyaan yang dijawab benar oleh siswa } \\
\text { dihubungkan dengan siswa lain yang menempuh } \\
\text { tes tersebut }\end{array}$ \\
\hline 2 & $\begin{array}{l}\text { Pengukur performance dalam } \\
\text { menempuh tes didasarkan pada standar } \\
\text { performance yang telah ditetapkan }\end{array}$ & Prestasi siswa adalah $80 \%$ dari siswa lain \\
\hline 3 & $\begin{array}{l}\text { Distribusi nilai tidak menyerupai kurve } \\
\text { normal }\end{array}$ & $\begin{array}{l}\text { Penilaian didasarkan pada apa adanya hasil } \\
\text { prestasi siswa }\end{array}$ \\
\hline 4 & $\begin{array}{l}\text { Didasarkan pada batas kelulusan } \\
(\mathrm{KKM})\end{array}$ & $\begin{array}{l}\text { Perolehan nilai berdasarkan pada } \\
\text { kelompok/kelas }\end{array}$ \\
\hline
\end{tabular}

c. Perbedaan PAP dan PAN ditinjau dari Maksud Tes

\begin{tabular}{|c|lr|lrr|}
\hline NO & \multicolumn{2}{|c|}{ CRT (PAP) } & \multicolumn{3}{c|}{ NRT (PAN) } \\
\hline 1 & $\begin{array}{l}\text { Dimaksudkan } \\
\text { mengklasifikasikan } \\
\text { mendiagnosa belajar siswa }\end{array}$ & untuk & Untuk mengadakan & seleksi & pada \\
individu/membuat rangking & & \\
\end{tabular}




\section{KESIMPULAN}

Dari berbagai penjelasan tersebut di atas maka dapat ditarik kesimpulan sebagai berikut:

1. Pengertian Kriteria ketuntasan minimal (KKM) adalah tingkat pencapaian kompetensi dasar mata pelajaran oleh peserta didik per mata pelajaran. Yang terdiri dari Jumlahkan nilai setiap komponen.

2. Teknik pemberian skor adalah merupakan langkah pertama dalam proses pengolahan hasil tes, penskoran adalah suatu proses pengubahan jawaban-jawaban tes menjadi angka-angka.

3. Penggunaan simbol untuk menyatakan nilai-nilai itu ada yang dengan angka, seperti angka dengan rentangan $0-10,0-100,0-4$, dan ada pula yang dengan huruf $\mathrm{A}, \mathrm{B}, \mathrm{C}, \mathrm{D}$, dan $\mathrm{E}$ Cara menskor hasil tes biasanya disesuaikan dengan bentuk soal-soal tes yang dipergunakan, apakah tes objektif atau tes essay, atau dengan bentuk lain.

\section{DAFTAR PUSTAKA}

SUPANDI, S., Khadijah, K., \& Arsyam, M. (2021). Tes standar dan tes non standar.

Fitriawan, F., Ansharwati, S., \& Arsyam, M. (2021, January 30). Hubungan Antara Taksonomi Tujuan Pendidikan Dan Evaluasi Hasl Belajar. Retrieved from osf.io/yaz6q

Yuliana, Y., Andi, A., \& Arsyam, M. (2021, January 30). Tekhnik Pembuatan Soal Dalam Pembelajaran. Retrieved from osf.io/zwu7k

Arifin, Zainal. 2009. Evaluasi Pembelajaran. Bandung: PT Remaja Rosdakarya.

Arikunto, Suharsimi. 2009. Dasar-dasar Evaluasi Pendidikan. Jakarta: BT Bumi Aksara.

Purwanto, Ngalim. 1994. Prinsip-prinsip dan Teknik Evaluasi Pengajaran. Bandung: PT Remaja Rosdakarya.

Salinan Lampiran Peraturan Menteri Pendidikan dan Kebudayaan Republik Indonesia Nomor 81A Tahun 2013.

Sukardi, M. 2015. Evaluasi Pendidikan (Prinsip dan Operasionalnya). Cet. 8. Jakarta: Bumi Aksara.

Ari Kunto Suharsisni, “Dasar-Dasar Evaluasi Pendidikan”, Bumi Aksara ; jakarta : 2012

Daryanto , "Evaluasi Pendidikan”, Rineka Cipta ; jakarta : 2008

Sanjaya Wina, “Perencanaan \& Desain Sistem Pembelajaran”, Kencana Prenada Media Grup ; jakarta : 2010

Sudjana Nana, “ Penilaian Hasil Proses Belajar Mengajar”, PT.Remaja Rusda Karya ; Bandung : 2006

Halwa, H., \& Arsyam, M. CIRI-CIRI, PRINSIP-PRINSIP, JENIS DAN PROSES EVALUASI PENDIDIKAN. 
Ramadani, W., Dahri, M., \& Arsyam, M. (2021, January 17). ADMINITRASI KEMITRAAN SEKOLAH DENGAN MASYAKARAT. https://doi.org/10.31219/osf.io/fpm9u

Arsi, A., Arsyam, M., \& Irma, I. administrasi tata kelola dalam pendidikan.

Djemari Mardapi. (2008). Teknik penyusunan instrumen tes dan non tes. Yogyakarta: Mitra Cendekia

Arsi, A., \& Arsyam, M. (2021). Administrasi Tata Kelola Dalam Pendidikan.

Nana Sudjana, Ibrahim, 2007,Penelitian dan Penilaian Pendidikan, Sinar Baru Algesindo,

Ramadani, W., Dahri, M., \& Arsyam, M. (2021). ADMINITRASI KEMITRAAN SEKOLAH DENGAN MASYAKARAT.

Neta, Y. (2014). Model Tata Kelola Administrasi Pemerintahan Yang Baik di Daerah Otonom Baru. FIAT JUSTISIA: Jurnal Ilmu Hukum, 6(2).

Fajrin, M. F., Rifqi, N., \& Arsyam, M. (2021). ADMINISTRASI KESISWAAN DALAM PENDIDIKAN.

Hardiansyah, H., \& Fahmi, A. (2018, September). Strategi Tata Kelola Administrasi Pada Perguruan Tinggi Berbasis Electronic Records. In Prosiding Seminar Nasional Lembaga Penelitian Dan Pendidikan (LPP) Mandala (pp. 246-250).

Janna, N. M., \& Arsyam, M. (2021). administrasi Keuangan dalam Pendidikan.

Mulyasa, Endang. 2007. Manajemen Berbasis Sekolah. Bandung: PT Remaja Rosdakarya.

Arsyam, M. (2020). Manajemen pendidikan islam.

Dahri, M., Ramadani, W., \& Arsyam, M. (2021). ADMINISTRASI EVALUASI DAN PENILAIAN DALAM PENDIDIKAN.

Griffin, P. \& Nix, P. (1991). Educational Assessment and Reporting. Sydney: Harcout Brace Javanovich, Publisher.

Undang-Undang Nomor 20 Tahun 2003 tentang Sistem Pendidikan Nasional. http//www.evaluasipendidikan.blogspot.com.

Ramadhani, W. S., Murti, M., \& Arsyam, M. (2021). TEKNIK PENGOLAHAN SKOR HASIL EVALUASI.

Farida Yusuf Tayibnapis. (2000). Evaluasi Program. Jakarta: Rineka Cipta

Arsyam, M., Jumliadi, M. H., \& Alwi, A. M. S. (2020). PEMBELAJARAN DIRUMAH DALAM LINGKUNGAN KELUARGA DI TENGAH PANDEMI COVID 19.

Astuti, S. (2016). Penerapan supervisi akademik untuk meningkatkan kompetensi guru dalam menyusun administrasi penilaian di sd laboratorium uksw. Scholaria: Jurnal Pendidikan dan Kebudayaan, 6(1), 117-126.

Arsyam, M. (2021). BAHAN AJAR ADMINISTRASI PENDIDIKAN.

Zakirah, Z., Jumliadi, J., Arsyam, M., Herianto, H., Rusli, M., \& Alwi, A. M. Implementation of The Islamic Local Regulations in Bulukumba Regency.

Zakirah, Z., Arsyam, M., HERIANTO, H., \& Umar, K. (2020, December 20). PENDIDIKAN DASAR

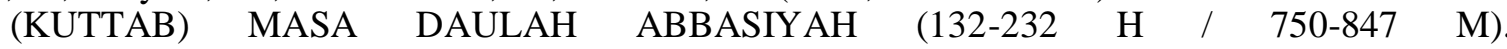
https://doi.org/10.31219/osf.io/7t8bs 
Makmur, Z., Arsyam, M., \& Alwi, A. M. S. (2020). Strategi Komunikasi Pembelajaran Di Rumah Dalam Lingkungan Keluarga Masa Pandemi. KOMUNIDA: Media Komunikasi dan Dakwah, 10(02), 231-241.

Arsyam, M. (2020). PENGARUH KEMAMPUAN SUPERVISIONAL KEPALA SEKOLAH DAN PERAN KOMITE SEKOLAH TERHADAP KINERJA GURU SMA NEGERI DI KOTA MAKASSAR. 